\title{
Changes in Soil Microbial Population and Enzymatic Activity under Different Plant Growth-Promoting Rhizobacteria and Weed Management Practices in Direct-Seeded Upland Rice
}

\author{
Jimni Phukan*, Jayanta Deka and Sontara Kalita \\ Department of Agronomy, College of Agriculture, Assam Agricultural University, \\ Jorhat-785013 (Assam), India \\ *Corresponding author
}

\begin{abstract}
A B S T R A C T
Keywords

Direct-seeded upland rice, Plant growth-promoting rhizobacteria, Pretilachlor, Pseudomonas fluorescens, Bacillus cereus, Phosphomonoesterace activity, Dehydrogenase activity

Article Info

Accepted:

24 July 2020

Available Online:

10 August 2020

A field experiment was carried out at Assam Agricultural University, Jorhat (Assam) in direct seeded rice (DSR) during autumn, 2018. The treatments consisted of three Plant growth-promoting rhizobacteria (PGPR) inoculations viz., Bacillus cereus, Pseudomonas fluorescens and no inoculation and four weed management practices viz., pretilachlor pre-emergence @ $0.75 \mathrm{~kg} / \mathrm{ha}$, pretilachlor pre- emergence @ 0.75 $\mathrm{kg} / \mathrm{ha}$ followed by one hand weeding at 30 DAS, three hand weedings at $15,30 \& 45$ DAS and weedy check. Results revealed that higher bacterial population was due to inoculation of Pseudomonas fluorescens which was followed by Bacillus cereus, but fungal population was found higher with the inoculation of Bacillus cereus followed by Pseudomonas fluorescens. Bacterial and fungal population and enzymatic activity decreased significantly due to either sole application of pretilachlor or in combination with hand weeding compared to three hand weeding and weedy check. The phosphomonoesterace and dehydrogenase activity were significantly higher with Pseudomonas fluorescens followed by Bacillus cereus. Grain and straw yield of DSR were higher with Pseudomonas fluorescens followed by Bacillus cereus and among weed management practices, it was higher with three hand weedings which was followed by pretilachlor pre-emergence @ $0.75 \mathrm{~kg} / \mathrm{ha}+$ one hand weeding at $30 \mathrm{DAS}$.

\section{Introduction}

Rice (Oryza sativa L.) is the staple food for more than $50 \%$ of the global population. India has the largest area under rice crop and ranked second in production next to China. Though direct-seeding of rice serves several advantages i.e. saves labour, early crop maturity, less water requirement and low

production cost etc., but weeds are the major threat to the production and adoption of DSR systems.

Hence, successful weed control is essential for obtaining optimum yield of rice. Sole application of pre-emergence herbicide alone cannot give a weed-free environment during the critical growth period of upland DSR.
\end{abstract}


Therefore, integrated weed management is essential for effective weed management and yield improvement in DSR.

The microbial community plays a critical role in regulating various soil processes such as decomposition of organic matter and nutrient cycling, so there is a keen interest in understanding the factors that regulate its size, activity and structure (Zeller et al., 2001).

PGPR are the root colonizing bacteria that produces beneficial effects on the growth of the host plant via direct or indirect mechanisms (Patel and Minocheherhomji, 2018) including nitrogen fixation, nutrient solubilisation, biosynthesis of phytohormone, siderophore, antibiotics, hydrolytic enzymes, exo-polysaccharide and induced systemic resistance in plants to their pathogen (Gupta et al., 2015). Improved growth and vigour of the crop might help in suppressing the associated weeds by an indirect way.

External application of xenobiotics may lead to variations in soil enzymatic activities. Soil enzymes are a group of enzymes usually present in soil that are continuously playing an important role in maintaining soil ecology and thus soil fertility and health. But herbicide application can alter growth of microorganisms, thereby soil enzymatic activities (Monkiedje et al., 2007). Types of herbicides, concentration, method of application, nature of the soil, environmental conditions etc affect the activities of enzymes in paddy soil.

Besides the type of soil and agricultural practices, soil enzymatic activities depend on the physico-chemical properties and quantity of the pesticide applied (Ramudu et al., 2011). So, keeping in view the above problems, this study was conducted with the objective of studying the performance of plant growth-promoting rhizobacteria and weed management on soil biology and yield of rice.

\section{Materials and Methods}

A field study was conducted during autumn, 2018 at Instructional-Cum-Research farm (ICR) of Assam Agricultural University, Jorhat (Assam). The soil of the experimental site was sandy loam in texture, acidic in reaction ( $\mathrm{pH}: 5.5)$, medium in organic carbon $(0.54 \%)$, low in available $\mathrm{N}(191 \mathrm{~kg} / \mathrm{ha}), \mathrm{P}_{2} \mathrm{O}_{5}$ $(22.28 \mathrm{~kg} / \mathrm{ha})$ and $\mathrm{K}_{2} \mathrm{O}(107.05 \mathrm{~kg} / \mathrm{ha})$. Seeds of rice variety 'Inglongkiri' @75 kg/ha were sown in rows $20 \mathrm{~cm}$ apart in individual plots of $4 \mathrm{~m} \times 3 \mathrm{~m}$ size. Crop was applied with $40: 20: 20$ of $\mathrm{N}: \mathrm{P}_{2} \mathrm{O}_{5}: \mathrm{K}_{2} \mathrm{O} \mathrm{kg} / \mathrm{ha}$ following the package of practices. The experiment was laid out in factorial randomized block design with three replications. The treatments consisted of three PGPR inoculations viz., Bacillus cereus, Pseudomonas fluorescens and no inoculation and four weed management practices viz., pretilachlor pre-emergence @ $0.75 \mathrm{~kg} / \mathrm{ha}$, pretilachlor pre- emergence @ $0.75 \mathrm{~kg} / \mathrm{ha}$ followed by one hand weeding at 30 DAS, three hand weedings at 15, 30 \& 45 DAS and weedy check.

The classical serial dilution technique was used for isolation of total bacterial and fungal population from soil by spread plate technique on appropriate media. Nutrient agar was used for counting total bacterial population, while Rose Bengal media was used for enumeration of fungal population. Antibiotic Streptomycillin sulphate was added in the melted media $\left(45^{\circ} \mathrm{C}\right)$ before plating. Aliquots of $100 \mu \mathrm{l}$ of $10^{-3}$ and $10^{-6}$ dilution were spread over the solidified media in triplicates. Nutrient agar and Rose Bengal media plates were incubated at $30^{\circ} \mathrm{C}$ for 2 days. The microbial number was estimated as $\log$ colony forming unit $(\mathrm{cfu}) / \mathrm{g}$ soil on dry weight basis. The method of Tabatabi and Bremner (1969) was followed to estimate the Phosphomonoesterase (PMEase) activity. Dehydrogenase activity was determined by the reduction of triphenyl tetrazolium chloride (TTC) to triphenyl formazon (TPF) as 
described by Casida et al., (1964) with modifications. The grain and straw yield were recorded after harvest and sun dried for 3 days. Harvest index was calculated using standard formula.

All the data pertaining to the present investigation wherever needed were statistically analysed. Critical differences (CD) at 5 per cent probability level was calculated only when the $\mathrm{F}$ value was found out to be significant.

\section{Results and Discussion}

\section{Bacterial and fungal populations}

The bacterial population increased significantly due to inoculation of Pseudomonas fluorescens which was followed by Bacillus cereus, but significantly higher fungal population was found with the inoculation of Bacillus cereus followed by Pseudomonas fluorescens as compared to no inoculation (Table 1). This might be due to multiplication of PGPR under favourable climatic condition or phytohormone released by the plants.

Among the weed management practices, the bacterial and fungal population decreased significantly at 60 DAS due to treatment with pretilachlor compared to three hand weedings and weedy check (Table 1). This could be due to the herbicide activity in the soil which could hamper the proliferation of microorganisms. Sahoo et al., (2016) reported that microbial population may be affected by herbicide application at recommended dose.

Interaction of Pseudomonas fluorescens with three hand weedings at 15, 30 and 45 DAS resulted in significantly higher bacterial population as compared to rest of the treatment combinations which might be due to absence of herbicide activity (Table 1A).

\section{Enzymatic activities}

The phosphomonoesterace and dehydrogenase activity were significantly higher with Pseudomonas fluorescens followed by Bacillus cereus compared to no inoculation (Table 1). Higher microbial population may lead to more microbial activity in soil which ultimately enhanced enzymes in soil.

Among the weed management practices, application of pretilachlor resulted lower enzymatic activities as compared to hand weedings and weedy check (Table 1). The inhibition of growth of most of the microorganisms due to herbicide activity might have led to decrease in production of phosphomonoesterace and dehydrogenase activities. Similar findings were reported by Latha and Gopal (2010).

Interaction of Pseudomonas fluorescens with both three hand weedings at 15, 30 and 45 DAS and weedy check as well as Bacillus cereus with three hand weedings and weedy check resulted in higher phosphomonoesterace and dehydrogenase activity compared to rest of the treatment combinations (Table 1A). This might be due to enhanced microbial activity under this treatment combination in absence of herbicidal effect on microbial population.

\section{Grain and straw yield}

Grain and straw yield of rice increased significantly due to Pseudomonas fluorescens inoculation as compared to other PGPR inoculation (Table 2) which might be due to increased availability of nitrogen and phosphorous as well as higher amount of cytokinin, gibberelin and auxin leading to better grain and straw yield (Jambhulkar and Sharma, 2013). 
Table.1 Effect of PGPR and weed management on microbial population and enzyme activity

\begin{tabular}{|c|c|c|c|c|c|c|}
\hline \multirow[t]{2}{*}{ Treatment } & \multirow{2}{*}{$\begin{array}{c}\begin{array}{c}\text { Bacterial } \\
\text { population } \\
\left(-\log \times 10^{-5} \mathrm{cfu} \mathrm{g}^{-1}\right. \\
\text { soil) }\end{array} \\
60 \text { DAS }\end{array}$} & \multirow{2}{*}{$\begin{array}{c}\text { Fungal population } \\
\left(-\log \times 10^{-5} \text { cfu g }^{-1} \text { soil }\right) \\
60 \text { DAS }\end{array}$} & \multicolumn{2}{|c|}{$\begin{array}{l}\text { Phosphomonoesterace activity } \\
\left(\mu \mathrm{g} \text { p-nitrophenol } \mathrm{g}^{-1} \text { dry soil } \mathbf{h r}^{-1}\right)\end{array}$} & \multicolumn{2}{|c|}{$\begin{array}{c}\text { Dehydrogenase activity } \\
\left(\mu \mathrm{g} \text { TPF } \mathrm{g} \mathrm{dry} \text { soil }^{-1} 7 \text { days }^{-1}\right)\end{array}$} \\
\hline & & & 60 DAS & At harvest & 60 DAS & At harvest \\
\hline \multicolumn{7}{|l|}{ PGPR } \\
\hline Bacillus cereus & 7.98 & 7.29 & 152.34 & 126.30 & 149.05 & 127.70 \\
\hline $\begin{array}{l}\text { Pseudomonas } \\
\text { fluorescens }\end{array}$ & 8.07 & 7.23 & 161.37 & 138.48 & 169.62 & 144.03 \\
\hline No inoculation & 7.93 & 7.16 & 114.76 & 113.85 & 129.32 & 92.77 \\
\hline SEM $( \pm)$ & 0.01 & 0.02 & 1.93 & 0.85 & 0.35 & 0.10 \\
\hline $\mathrm{CD}(\mathrm{P}=\mathbf{0 . 0 5})$ & 0.03 & 0.05 & 5.67 & 2.48 & 1.03 & 0.30 \\
\hline \multicolumn{7}{|l|}{ Weed Management } \\
\hline Pretilachlor@0.75 kg/ha & 7.93 & 7.20 & 121.85 & 120.85 & 130.87 & 110.50 \\
\hline $\begin{array}{l}\text { Pretilachlor @ } 0.75 \mathrm{~kg} / \mathrm{ha} \\
+ \text { one hand weeding at } \\
30 \text { DAS }\end{array}$ & 7.92 & 7.17 & 126.38 & 118.34 & 131.81 & 110.61 \\
\hline $\begin{array}{l}\text { Three hand weedings at } \\
15,30 \text { and } 45 \text { DAS }\end{array}$ & 8.07 & 7.24 & 159.87 & 132.01 & 167.38 & 132.38 \\
\hline Weedy check & 8.05 & 7.29 & 163.21 & 133.65 & 167.24 & 132.51 \\
\hline $\operatorname{SEM}( \pm)$ & 0.01 & 0.02 & 2.23 & 0.98 & 0.41 & 0.10 \\
\hline $\mathrm{CD}(\mathrm{P}=\mathbf{0 . 0 5})$ & 0.04 & 0.06 & 6.55 & 2.86 & 1.19 & 0.30 \\
\hline \multicolumn{7}{|l|}{ Interaction $(\mathbf{P} \times \mathbf{W})$} \\
\hline $\operatorname{SEM}( \pm)$ & 0.02 & 0.04 & 3.87 & 1.69 & 0.71 & 0.20 \\
\hline $\mathrm{CD}(\mathrm{P}=\mathbf{0 . 0 5})$ & 0.06 & NS & 11.35 & NS & 2.07 & 0.59 \\
\hline
\end{tabular}


Table.1A Interaction effect of PGPR and weed management on bacterial population, phosphomonoesterace and dehydrogenase activity

\begin{tabular}{|c|c|c|c|c|c|c|c|c|c|c|c|c|}
\hline \multirow{3}{*}{$\begin{array}{l}\text { Weed } \\
\text { management }\end{array}$} & \multicolumn{12}{|c|}{ PGPR } \\
\hline & \multicolumn{3}{|c|}{ Bacterial population } & \multicolumn{3}{|c|}{$\begin{array}{c}\text { Phosphomonoesterace } \\
\text { activity (60 DAS) }\end{array}$} & \multicolumn{3}{|c|}{ dehydrogenase activity ( 60 DAS) } & \multicolumn{3}{|c|}{ dehydrogenase activity (harvest) } \\
\hline & $\mathbf{P}_{1}$ & $\mathbf{P}_{2}$ & $\mathbf{P}_{3}$ & $\mathbf{P}_{1}$ & $\mathbf{P}_{2}$ & $\mathbf{P}_{3}$ & $\mathbf{P}_{1}$ & $\mathbf{P}_{2}$ & $\mathbf{P}_{3}$ & $\mathbf{P}_{1}$ & $\mathbf{P}_{2}$ & $\mathbf{P}_{\mathbf{3}}$ \\
\hline $\mathbf{W}_{1}$ & 7.91 & 7.97 & 7.89 & 128.16 & 130.85 & 106.53 & 129.00 & 147.10 & 116.51 & 116.27 & 129.62 & 85.62 \\
\hline $\mathbf{W}_{2}$ & 7.93 & 8.01 & 7.84 & 129.62 & 133.67 & 115.86 & 132.95 & 152.05 & 110.44 & 120.08 & 131.47 & 80.28 \\
\hline $\mathbf{W}_{3}$ & 8.05 & 8.19 & 7.98 & 172.07 & 186.62 & 120.92 & 167.46 & 189.71 & 144.98 & 137.35 & 157.37 & 102.43 \\
\hline $\mathbf{W}_{4}$ & 8.03 & 8.10 & 8.02 & 179.52 & 194.36 & 115.75 & 166.77 & 189.63 & 145.34 & 137.10 & 157.68 & 102.75 \\
\hline $\operatorname{SEM}( \pm)$ & \multicolumn{3}{|c|}{0.02} & \multicolumn{3}{|c|}{3.87} & \multicolumn{3}{|c|}{0.71} & \multicolumn{3}{|c|}{0.20} \\
\hline $\mathrm{CD}(\mathrm{P}=\mathbf{0 . 0 5})$ & \multicolumn{3}{|c|}{0.06} & \multicolumn{3}{|c|}{11.35} & \multicolumn{3}{|c|}{2.07} & \multicolumn{3}{|c|}{0.59} \\
\hline
\end{tabular}

$\mathrm{W}_{1}$ : Pretilachlor @ $0.75 \mathrm{~kg} / \mathrm{ha}, \mathrm{W}_{2}$ : Pretilachlor @ $0.75 \mathrm{~kg} / \mathrm{ha}+$ one hand weeding at $30 \mathrm{DAS}, \mathrm{W}_{3}$ : Three hand weedings at 15,30 and $45 \mathrm{DAS}, \mathrm{W}_{4}$ : Weedy check, $\mathrm{P}_{1}$ : Bacillus cereus,

$\mathrm{P}_{2}$ : Pseudomonas fluorescens, $\mathrm{P}_{3}$ : No inoculation

Table.2 Effect of PGPR and weed management on grain yield, straw yield and harvest index

\begin{tabular}{|c|c|c|c|}
\hline Treatment & Grain yield (q/ha) & Straw yield (q/ha) & Harvest index (\%) \\
\hline \multicolumn{4}{|l|}{ PGPR } \\
\hline Bacillus cereus & 13.91 & 18.24 & 43.3 \\
\hline Pseudomonas fluorescens & 16.63 & 21.44 & 43.7 \\
\hline No inoculation & 11.50 & 15.52 & 42.6 \\
\hline $\operatorname{SEM}( \pm)$ & 0.44 & 0.54 & - \\
\hline CD $(\mathbf{P}=\mathbf{0 . 0 5})$ & 1.28 & 1.59 & - \\
\hline Pretilachlor@0.75 kg/ha + one hand weeding at 30 DAS & 18.84 & 21.92 & 46.2 \\
\hline Three hand weedings at 15,30 and 45 DAS & 20.48 & 23.76 & 46.3 \\
\hline Weedy check & 6.04 & 11.43 & 34.6 \\
\hline $\operatorname{SEM}( \pm)$ & 0.50 & 0.62 & - \\
\hline $\mathrm{CD}(\mathbf{P}=\mathbf{0 . 0 5})$ & 1.47 & 1.83 & - \\
\hline $\operatorname{SEM}( \pm)$ & 0.87 & 1.08 & - \\
\hline $\mathrm{CD}(\mathbf{P}=\mathbf{0 . 0 5})$ & 2.55 & 3.17 & - \\
\hline
\end{tabular}


Table.3 Interaction effect of PGPR and weed management on grain and straw yield

\begin{tabular}{|l|c|c|c|c|c|c|}
\hline \multirow{2}{*}{ Weed management } & \multicolumn{9}{|c|}{ PGPR } \\
\cline { 2 - 8 } & \multicolumn{3}{|c|}{ Grain yield (q/ha) } & \multicolumn{3}{c|}{ Straw yield (q/ha) } \\
\hline $\mathbf{W}_{\mathbf{1}}$ & $\mathbf{P}_{\mathbf{1}}$ & $\mathbf{P}_{\mathbf{2}}$ & $\mathbf{P}_{\mathbf{3}}$ & $\mathbf{P}_{\mathbf{1}}$ & $\mathbf{P}_{\mathbf{2}}$ & $\mathbf{P}_{\mathbf{3}}$ \\
\hline $\mathbf{W}_{\mathbf{2}}$ & 9.90 & 12.63 & 9.53 & 16.23 & 17.83 & 15.40 \\
\hline $\mathbf{W}_{\mathbf{3}}$ & 18.60 & 22.00 & 15.97 & 21.17 & 26.27 & 18.33 \\
\hline $\mathbf{W}_{\mathbf{4}}$ & 22.00 & 23.60 & 15.83 & 23.23 & 29.03 & 19.00 \\
\hline $\mathbf{S E M}(\mathbf{\pm})$ & 5.13 & 8.33 & 4.67 & 12.33 & 12.63 & 9.33 \\
\hline $\mathbf{C D}(\mathbf{P = 0 . 0 5})$ & & 0.87 & & & 1.08 & \\
\hline
\end{tabular}

$\mathrm{W}_{1}$ : Pretilachlor @ $0.75 \mathrm{~kg} / \mathrm{ha}, \mathrm{W}_{2}$ : Pretilachlor @ $0.75 \mathrm{~kg} / \mathrm{ha}+$ one hand weeding at $30 \mathrm{DAS}, \mathrm{W}_{3}$ : Three hand weedings at 15,30 and 45 DAS, $\mathrm{W}_{4}$ : Weedy check, $\mathrm{P}_{1}$ : Bacillus cereus, $\mathrm{P}_{2}$ : Pseudomonas fluorescens, $\mathrm{P}_{3}$ : No inoculation

Among the weed management practices, three hand weedings at 15,30 and 45 DAS recorded significantly higher grain and straw yield which was followed by pretilachlor @ $0.75 \mathrm{~kg} / \mathrm{ha}+$ one hand weeding at $30 \mathrm{DAS}$ as compared to single application of Pretilachlor @ $0.75 \mathrm{~kg} / \mathrm{ha}$ and weedy check (Table 2). This might be due to better management of weeds at critical stages of crop growth under these two treatments. Similar results were obtained by Maity and Mukherjee (2011).

The PGPR and weed management treatments interacted significantly in regards to grain and straw yield. The highest values were obtained with the combination of Pseudomonas fluorescens and three hand weedings at 15, 30 and 45 DAS which was at par with grain and straw yield achieved from the combination of Pseudomonas fluorescens and pretilachlor@ $0.75 \mathrm{~kg} / \mathrm{ha}+$ one hand weeding at 30 DAS (Table. 3).

\section{Harvest index}

Inoculation of Pseudomonas fluorescens resulted highest harvest index (43.7) followed by Bacillus cereus (43.3) and no inoculation (42.6) (Table 2). Higher dry matter accumulation and its efficient mobilization into grains due to Pseudomonas fluorescens might have resulted higher harvest index. In respect of weed management practices, three hand weedings at 15,30 and 45 DAS resulted highest harvest index (46.3) closely followed by pretilachlor @ $0.75 \mathrm{~kg} / \mathrm{ha}+$ one hand weeding at 30 DAS (46.2). A good crop growth and a better partitioning of the dry matter to reproductive parts under these treatments might have caused higher harvest index.

It was concluded that the bacterial and fungal populations increased with the inoculation of PGPR resulting in improved enzymatic activities in the soil that might increase nutrient availability to the crop which ultimately resulted higher yield of rice. The application of pretilachlor reduced both the microbial population as well as the enzymatic activity. So, the higher grain and straw yield with three hand weedings might be due to improved crop growth under weed free conditions. Combination of hand weedings with Pseudomonas fluorescens resulted in better soil biological activities as well as yield of rice.

\section{Acknowledgements}

The authors would like to acknowledge the Assam Agricultural University, Jorhat for sponsoring the study. 


\section{References}

Casida, Jr. L.E., Klein, D.A. and Santoro, T. (1964). Soil dehydrogenase activity. Soil science. 98(6): 371-376.

Gupta, G., Parihar, S.S., Ahirwar, N.K., Snehi, S.K. and Singh V. (2015). Plant growth promoting rhizobacteria (PGPR): current and future prospects for development of sustainable agriculture. Journal of Microbiology and Biochemical Technology. 7(2): 096-102.

Jambhulkar, P.P. and Sharma, P. (2013). Promotion of rice seedling growth characteristics by development and use of bioformulation of Pseudomonas fluorescens. Indian Journal of Agricultural Sciences. 83(2): 136-142.

Latha, P.C. and Gopal, H. (2010). Effect of Rice Herbicides on $\beta$-glucosidase, Protease and Alkaline Phosphatase Activity in Soil. Indian Journal of Weed Science. 42(3\&4): 223-225.

Maity, S. K., and Mukherjee, P. K. (2011). Effect of brown manuring on grain yield and nutrient use efficiency in dry direct seeded Kharif rice (Oryza sativa L.). Indian Journal of Weed Science. 43(1\&2): 61-66.

Monkiedje, A., Spiteller, M., Maniepi, S.J.N. and Sukul, P. (2007). Influence of metalaxyl-and mefenoxam-based fungicides on chemical and biochemical attributes of soil quality under field conditions in a southern humid forest zone of Cameroon. Soil Biology and Biochemistry. 39(4): 836-842.

Patel, S.T. and Minocheherhomji, F.P. (2018). Plant Growth Promoting Rhizobacteria: Blessing to Agriculture. International Journal of Pure and Applied Bioscience. 6: 481-492.

Ramudu, A.C., Mohiddin, G.J., Srinivasulu, M., Madakka, M. and Rangaswamy, V. (2011). Impact of fungicides chlorothalonil and propiconazole on microbial activities in groundnut (Arachis hypogaea L.) soils. ISRN microbiology.

Sahoo, S., Adak, T., Bagchi, T.B., Kumar, U., Munda, S., Saha, S., Barliner, J., Mayabini, J. and Mishra, B.B. (2016). Non-target effects of pretilachlor on microbial properties in tropical rice soil. Environmental Science and Pollution Research. 23(8): 7595-7602.

Tabatabai, M.A. and Bremner, J.M. (1969). Use of p-nitrophenyl phosphate for assay of soil phosphatase activity. Soil biology and biochemistry. 1(4): 301307.

Zeller, V., Bardgett, R.D., and Tappeiner, U. (2001). Site and management effects on soil microbial properties of subalpine meadows: a study of land abandonment along a north-south gradient in the European Alps. Soil Biology and Biochemistry. 33(4-5): 639-649.

\section{How to cite this article:}

Jimni Phukan, Jayanta Deka and Sontara Kalita. 2020. Changes in Soil Microbial Population and Enzymatic Activity under Different Plant Growth-Promoting Rhizobacteria and Weed Management Practices in Direct-Seeded Upland Rice. Int.J.Curr.Microbiol.App.Sci. 9(08): 3136-3142. doi: https://doi.org/10.20546/ijcmas.2020.908.357 